\title{
Morphometric analysis of young petiole galls on the narrow-leaf cottonwood, Populus angustifolia, by the sugarbeet root aphid, Pemphigus betae
}

\author{
Ryan A. Richardson ${ }^{1}$. Mélanie Body ${ }^{1} \cdot$ Michele R. Warmund $^{2} \cdot$ Jack C. Schultz $^{1}$. \\ Heidi M. Appel ${ }^{1}$ (1)
}

Received: 21 September 2015 / Accepted: 21 December 2015 / Published online: 6 January 2016

(C) The Author(s) 2015. This article is published with open access at Springerlink.com

\begin{abstract}
An insect-induced gall is a highly specialized structure resulting from atypical development of plant tissue induced by a reaction to the presence and activity of an insect. The insect induces a differentiation of tissues with features and functions of an ectopic organ, providing nutrition and protection to the galling insect from natural enemies and environmental stresses. In this anatomical and cytological study, we characterized how the gall-inducing aphid Pemphigus betae reshapes the leaf morphology of the narrow-leaf cottonwood Populus angustifolia to form a leaf fold gall. Young galls displayed a bend on one side of the midvein toward the center of the leaf and back to create a fold on the abaxial side of the leaf. This fold was formed abaxially by periclinal and anticlinal divisions, effectively eliminating intercellular spaces from the spongy parenchyma. Galls at this stage exhibited both cell hypertrophy and tissue hyperplasia. Cells on the adaxial surface were more numerous and smaller than cells near the abaxial surface were, creating the large fold that surrounds the insect. Mesophyll cells exhibited some features typical of nutritive cells induced by other galling insects, including conspicuous nucleolus, reduced and fragmented vacuole, smaller and degraded chloroplasts, and dense cytoplasm compared to ungalled tissue. Even though aphids feed on the
\end{abstract}

Handling Editor: Hanns H. Kassemeyer

Heidi M. Appel

appelh@missouri.edu

1 Division of Plant Sciences, Christopher S. Bond Life Sciences Center, University of Missouri, 1201 Rollins Street, Columbia, MO 65211, USA

2 Division of Plant Sciences, Department of Horticulture, University of Missouri, 1-31 Agriculture Building, Rollins Street,

Columbia, MO 65211, USA contents of phloem and do not directly consume the gall tissue, they induce changes in the plant vascular system, which lead to nutrient accumulation to support the growing aphid numbers in mature galls.

Keywords Gall-inducing insect · Galling aphid . Morphological alterations $\cdot$ Nutritive tissue $\cdot$ Microscopy

\section{Introduction}

Galls are highly specialized structures arising from atypical development of plant tissue induced by another organism. Many different kinds of organisms can induce galls on plants, including viruses, fungi, bacteria, nematodes, mites, and insects (Redfern 2011). However, insects make galls that are more structurally consistent and diverse than those made by all other gall-inducing organisms (Imms 1947; Price et al. 1987). Galling has evolved repeatedly among and within insect orders: Hymenoptera, Diptera, Hemiptera, Lepidoptera, Coleoptera, and Thysanoptera (Stone and Schönrogge 2003). An estimated 15,000 insect species manipulate the development of their host plants in a species-specific manner to generate galls within which the insect feeds. Insect galls are distinguished from other insect-generated shelters (such as rolled leaves or leaf mines) by the active differentiation and growth of plant tissues with features of a novel organ (Mani 1964; Stone and Schönrogge 2003; Shorthouse et al. 2005; Giron et al. 2015). These structures are thought to provide adaptive advantages to gall feeders of enhanced nutrition and protection of the galling insect against natural enemies and environmental stresses (Mani 1964; Price et al. 1987; Hartley and Lawton 1992; Hartley 1998; Nyman and Julkunen-Tiitto 2000; Stone et al. 2002; Nakamura et al. 2003; Stone and Schönrogge 2003; Allison and Schultz 2005; Motta et al. 2005; Ikai and Hijii 
2007; Diamond et al. 2008; Formiga et al. 2009; Compson et al. 2011; Formiga and Isaias 2011; Nabity et al. 2013).

Gall formation is a complex and close interaction between the insect and the host plant resulting from molecular cross-talk between two independent genomes. The inducer manipulates the host plant signaling by injecting effectors (small molecules that alter host cell structure and function and modulate plant response) into the wound while initiating interaction with the host (during feeding and/or oviposition depending on insect species) to redirect normal plant development (Chen et al. 2010; Hogenhout and Bos 2011; Giron et al. 2015). The chemical identity and mode of action of the inducing compounds in these secretions, and the plant developmental pathways that they affect, remain unclear (Giron et al. 2015). Unlike the host genetic transformation used by Agrobacterium tumefaciens to cause crown gall on plants, insect galls are not thought to involve host genetic transformation because insect gall development stops if the insect is removed. Diverse chemical signals have been proposed in insect gall systems, including phytohormones (especially plant growth factors: auxins and/or cytokinins) (Cornell 1983; Shorthouse and Rohfritsch 1992; Suzuki et al. 2014; Tooker and Helms 2014), amino acids (Stone and Schönrogge 2003), proteins (Higton and Mabberly 1994), mutualistic viruses (Cornell 1983), or bacterial symbionts (Yamaguchi et al. 2012). Whatever their nature, these chemical signals generate galls with morphological phenotypes characteristic of each inducing species (Rohfritsch 1992; Williams 1994; Crespi and Worobey 1998; Stone and Schönrogge 2003). Some plant species support a comparatively rich fauna (two or more species) of insect galls, each with different morphological features (Formiga et al. 2015). For example, up to 70 distinct gall structures may be present on a single oak, each caused by a different insect species (Stone and Schönrogge 2003; Stone G, personal communication). Although more rare in nature, the same insect species can induce morphologically similar galls in different host plants, which is evidence that galling insects can play a major role in determining gall morphology (Price et al. 1987; Stone and Schönrogge 2003; Muñoz-Viveros et al. 2014). In some lineages, especially gall wasps (Hymenoptera, Cynipidae) and gall midges (Diptera: Cecidomyiidae), gall formation involves elaborate complex external structures, including extrafloral nectaries, hair, spines, and sticky resins (Stone and Schönrogge 2003). Thus, the insect gall phenotype is a product of a chemical communication between the host plant and the gall-inducer and is under the influence of both the insect and the plant genotypes. Indeed, galls are commonly considered to be the extended phenotype of the gall inducer (Dawkins 1982), with the developmental program of plant cells altered toward new shape and function.

Gall-inducing insects have different ways of harvesting the plant food. Some gallers are biting/chewing insects (caterpillar-like) that consume plant cells by macerating entire tissues and rupturing cells with their mandibles in the process, whereas other gallers have piercing/sucking mouthparts (aphid-like) and penetrate plant tissue with their stylets allowing them to reach the vascular elements to feed on plant sap (Forbes 1977; Schoonhoven et al. 2005; Chapman 2013). Depending on these feeding habits, specialized nutritive tissues may differentiate. Galls, especially those induced by Cecidomyiidae and Cynipidae, usually contain a highly differentiated nutritive layer that lines the central chamber and is consumed by the larva during its development (Rohfritsch 1977; Bronner 1992). However, other galling-insects, such as psyllids, aphids, and their relatives, induce limited changes in host tissue that is called a nutritive-like layer (Álvarez et al. 2009; Oliveira and Isaias 2010b; Isaias and Oliveira 2012; Carneiro and Isaias 2015a, b). The nutritive cells usually display a common set of cytological features, even though other aspects of gall morphology and organization can vary widely (Muñoz-Viveros et al. 2014). The chlorenchyma cells within the nutritive tissue are generally homogenous and usually includes a large nucleus, conspicuous nucleolus, high enzymatic activity, RNA richness, fragmented vacuole, numerous mitochondria, a dense/abundant cytoplasm, and the accumulation of carbohydrates (and lipids in some systems) (Bronner 1992). These cells also have thin walls and reduced intercellular spaces that are characteristic of young, fast-growing tissues (Castro et al. 2012; Vecchi et al. 2013; Carneiro and Isaias 2015a). The lack of intercellular spaces indicates the occurrence of little gas exchange and consequent reduced photosynthetic metabolism (Carneiro and Isaias 2015a). Chloroplasts and mitochondria are numerous and poorly differentiated, often leading to photosynthesis-deficient cells within the galls (Bronner 1992; Huang et al. 2014; Carneiro and Isaias 2015a). Understanding these insect-induced cytological changes may help elucidate how the insect induces gall formation.

In this study, we focus on aphid galls formed on narrowleaf cottonwood trees because they have ecological and genetic resources that will facilitate future mechanistic studies of gall formation. The narrowleaf cottonwood, Populus angustifolia, is a foundation tree species for about 700 insect species, soil microbial communities, lichens, fungi, beavers, and birds (Whitham et al. 2006, 2008). The presence or absence of the leaf-galling aphid Pemphigus betae is determined by susceptible or resistant poplar genotypes and affects other trophic levels by altering the composition of a diverse community of fungi, insects, spiders, and avian predators (Whitham et al. 2006, 2008). The Pemphigus aphid and other communities of arthropods on narrowleaf cottonwood alter the chemistry (such as sugar and condensed tannin contents) within the tree which in turn affects other species that depend on the tree, leading to major community and ecosystem consequences (Larson and Whitham 1991; Whitham et al. 2006). 
This Populus-Pemphigus system has been studied by ecologists for over three decades to understand the interactions among all species in the ecosystem, but the mechanism of gall formation is unknown. As its common name implies, the sugarbeet root aphid uses other plant species as secondary hosts, including sugarbeet, an important crop for sucrose production in the northern USA (Larson and Whitham 1991). P. betae causes significant reductions in sugarbeet yield and reduces sucrose quality. For example, in 1989, a Pemphigus infestation reduced the sugar content and recoverable sugar by 64 and $73 \%$, respectively, resulting in a $\$ 3,000,000$ loss or about $\$ 925$ per infested hectare (Hutchinson and Campbell 1994). Thus, an understanding of the mechanism of gall development by $P$. betae would provide important insight into its ecological role and economic impact. The first step in that understanding is to characterize the morphological changes occurring during gall formation.

To gain insight into potential mechanisms of gall formation, we characterized how the galling insect $P$. betae reshapes the leaf morphology of the narrowleaf cottonwood, $P$. angustifolia, during the first stages of gall development. Using morphological and morphometric analyses, we characterized the alterations induced by the insect in the host plant during the first stages of gall development. We expected $P$. betae galls to (i) grow via cell hypertrophy and/or tissue hyperplasia, (ii) present an accumulation of nutrients in galled tissues as Larson and Whitham (1991) suggested as necessary to support the increasing demand of the growing colony of $P$. betae, and (iii) not display a true nutritive tissue as the aphid feeds on phloem contents.

\section{Material and methods}

\section{Study system}

The sugarbeet root aphid P. betae (Hemiptera: Aphididae) induces galls on leaves of the narrowleaf cottonwood $P$. angustifolia (Salicaceae) (Harper 1959). The life cycle of $P$. betae in North America is an example of the holocycle (Fig. 1) (Moran and Whitham 1988). Each gall (size of mature galls: $\sim 25 \mathrm{~mm}$ long, 6 mm deep; Harper 1959) is induced by a single aphid (a fundatrix or stem mother) in the spring on their primary host poplar leaves (preferentially at their base) that are only a tenth to a quarter of their mature size (size of mature leaf: 50-90 mm long, 10-25 mm wide; USDA-NRCS 2008). Secondary hosts of $P$. betae include sugarbeets (from which the common name "sugarbeet root aphid" originates), carrots, turnips, Swiss chard, spinach, and lettuce, where they feed during the summer without inducing galls (Harper 1959; Moran and Whitham 1988; Larson and Whitham 1991; Moran 1991).

\section{Sample collection}

Ungalled (control) and galled narrowleaf cottonwood leaves were collected in the field (Ogden Nature Center, Ogden UT, USA) in May 2008. We focused on developing leaves with young galls to study the first stages of gall development (Fig. 1, steps 3 and 4 before fundatrices start to reproduce). Leaves were $36.58 \pm 0.78 \mathrm{~mm}$ long and $10.85 \pm 0.26 \mathrm{~mm}$ wide with galls that were $5.96 \pm 0.65 \mathrm{~mm}$ long, $1.73 \pm 0.27 \mathrm{~mm}$ wide, and $1.41 \pm 0.12 \mathrm{~mm}$ deep. Leaves and associated galling aphids were immediately fixed in $5 \%$ glutaraldehyde in $50 \mathrm{mM}$ sodium phosphate solution ( $\mathrm{pH} 7$ ). Excess leaf tissues were removed in the lab, and samples were cut to the appropriate size for further sectioning.

\section{Light microscopy}

Leaf samples $(N=4$ for controls and $N=5$ for galls) were processed for light microscopy at IDEXX RADIL (BioResearch Laboratory, Columbia MO, USA). Samples were dehydrated in ethanol series, embedded in paraffin wax, and sectioned at 4-6 $\mu \mathrm{m}$ thick on a sliding microtome. Samples were stained with $0.5 \%$ toluidine blue for $5 \mathrm{~min}$, briefly rinsed in tap water, rinsed twice in $95 \%$ alcohol for $1 \mathrm{~min}$ each, and rinsed twice in $100 \%$ alcohol for $1 \mathrm{~min}$ each. Samples were then cleared in two changes of xylene and mounted on slides with mounting media and a coverslip (McManus and Mowry 1960). Toluidine blue was used to highlight general histological features. Images of ungalled control and galled tissues were acquired with a Leica 5500B light microscope (Leica Microsystems, Germany) equipped with a Leica DFC290 camera and the Leica Application Suite v.4.6.0 software at the Molecular Cytology Core, University of Missouri (Columbia MO, USA).

\section{Transmission electron microscopy}

Leaf samples ( $N=5$ for controls and $N=8$ for galls) were processed for transmission electron microscopy (TEM) at the Electron Microscopy Core Facility (University of Missouri, Columbia MO, USA). Unless otherwise stated, all reagents were purchased from Electron Microscopy Sciences (Hatfield PA, USA). Tissues were fixed in $5 \%$ glutaraldehyde in $50 \mathrm{mM}$ sodium phosphate solution ( $\mathrm{pH} 7$ ), then rinsed with $100 \mathrm{mM}$ sodium cacodylate buffer $(\mathrm{pH}$ 7.35) containing $10 \mathrm{mM}$ 2-mercaptoethanol (Sigma Aldrich, St. Louis MO, USA) and $130 \mathrm{mM}$ sucrose (further referred to as 2-ME buffer). Secondary fixation was performed with $1 \%$ osmium tetroxide in 2-ME buffer using a Pelco Biowave (Ted Pella Inc., Redding CA, USA) operated at $100 \mathrm{~W}$ for $1 \mathrm{~min}$. Specimens were then incubated at $4{ }^{\circ} \mathrm{C}$ for $1 \mathrm{~h}$, rinsed with 2-ME buffer followed by distilled water. Samples were then dehydrated using the Pelco Biowave, a graded ethanol dehydration series 
(1)
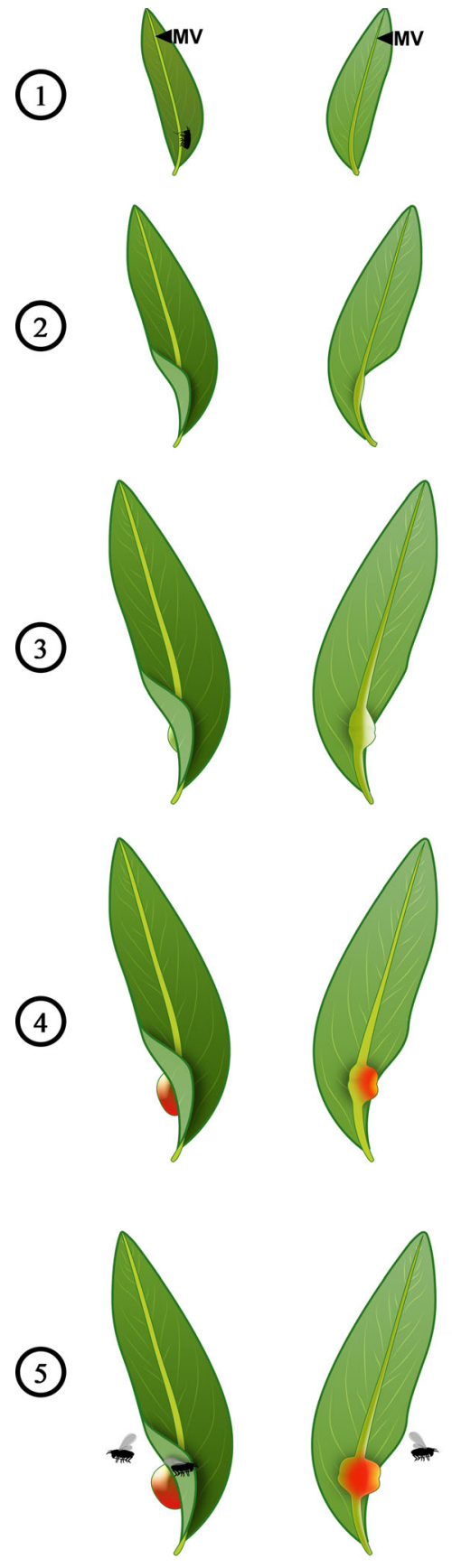

Fig. 1 Pemphigus betae life cycle and gall ontogeny on its primary host plant, Populus angustifolia. Representations of galled leaves viewed from the upper/adaxial surface (left) and the lower/abaxial surface (center) of the leaf, as well as a cross-section (right), were compiled from the literature and results of this study (Harper 1959; Dunn 1960; Whitham 1979, 1980; Moran and Whitham 1988; Larson and Whitham 1991; Moran 1991; Whitham 1992; Wool 2004). 1, In the spring, fundatrix nymphs emerge from overwintered eggs laid beneath the bark of poplar trees and colonize leaves just as the buds begin to open. Galls are initiated by a single stem mother along the midvein of an expanding leaf by probing the leaf tissue with her stylet moving between parenchyma cells to reach the phloem cells. 2, Growth is arrested at the stylet insertion site, leading to the formation of a small depression on the leaf and causing the petiole to
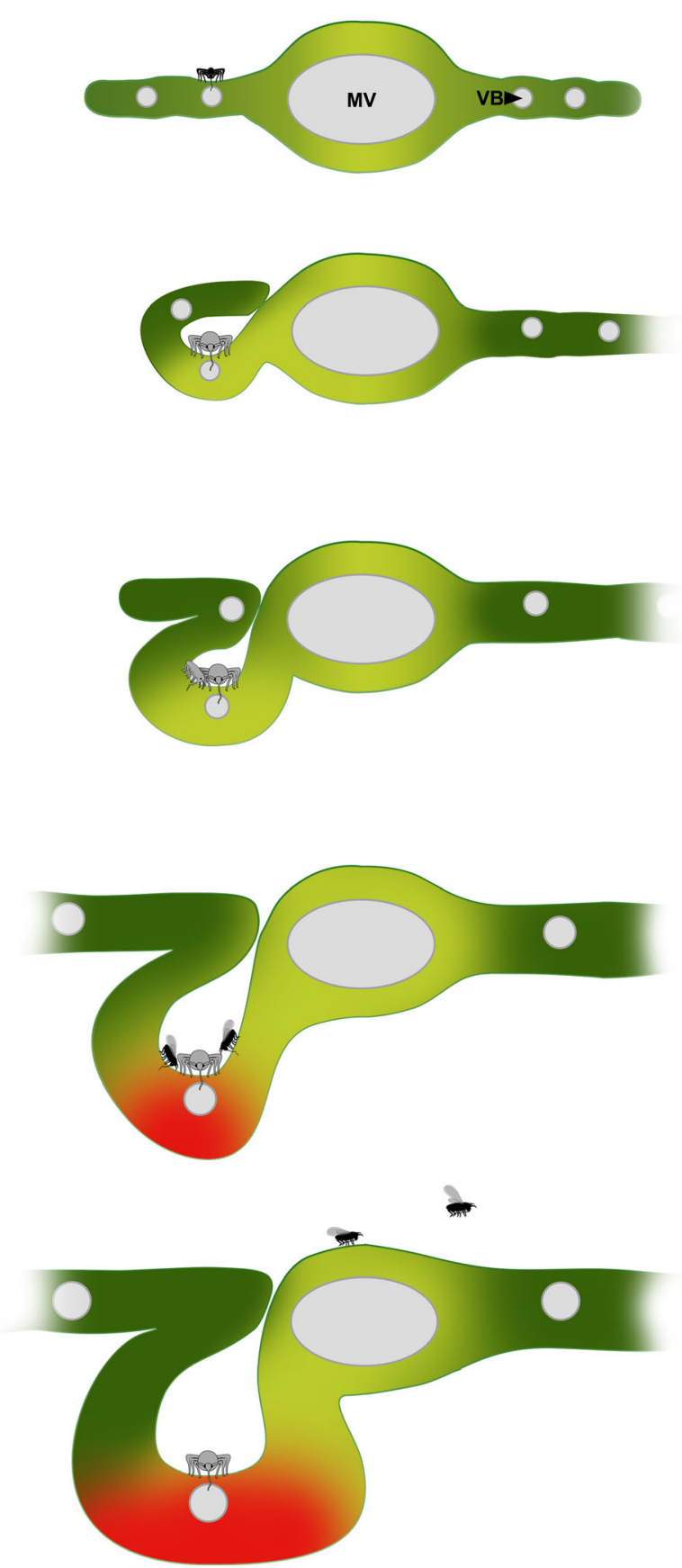

bend toward this area. 3, Leaf tissue on one side of the midvein folds toward the center of the leaf and then back to create a fold on the abaxial side of the leaf. The fundatrix begins to parthenogenetically and viviparously produce a generation of several hundred (up to 300) apterate offspring. 4, The wingless gall occupants become alate (winged). 5, Alates disperse from the gall to deposit their larvae in the ground. These larvae colonize the roots of herbaceous secondary hosts where they feed during the summer without inducing galls. In the fall, alate sexuparae emerge from the roots, fly back to the poplar, and asexually produce sexual males and females. Their sexual reproduction produces a single egg (future fundatrix) in each female that is deposited in a tree bark crevice to overwinter. Structures not to scale for practical reasons. $M V$ midvein with vascular bundles, $V B$ vascular bundle 
(per exchange, $100 \mathrm{~W}$ for $40 \mathrm{~s}$ ), transitioned into acetone, and then infiltrated with Epon/Spurr's resin ( $250 \mathrm{~W}$ for $3 \mathrm{~min}$ ) and polymerized at $60{ }^{\circ} \mathrm{C}$ overnight. Next, embedded tissue was cut to a thickness of $85 \mathrm{~nm}$ using a microtome (Ultracut UCT, Leica Microsystems, Germany) and a diamond knife (Diatome, Hatfield PA, USA). These sections were post-stained with Reynolds lead citrate stain (Reynolds 1963) and $5 \%$ aqueous uranyl acetate. Images of cells from upper epidermis, palisade parenchyma, and spongy parenchyma (first few layers) of ungalled control and galled tissues were acquired with a JEOL JEM 1400 transmission electron microscope (JEOL, Peabody MA, USA) at $80 \mathrm{kV}$ on a Gatan Ultrascan 1000 CCD (Gatan Inc., Pleasanton CA, USA).

\section{Image analysis}

Light and TEM images were analyzed with the Image J version $1.49 \mathrm{~m}$ software (National Institutes of Health, USA) and the Fiji plugin. Thirty-six light microscopy images from nine samples ( $N=4$ for controls and $N=5$ for galls) were used for counting cells in a $100-\mu \mathrm{m}$ wide transect from adaxial to abaxial surfaces and for measuring gall/leaf thickness. Cell number was determined for each tissue type (upper epidermis, palisade parenchyma, spongy parenchyma, lower epidermis, and vascular bundle) and expressed as cell number per tissue type in the $100-\mu \mathrm{m}$ transect. Cell density was determined by dividing the number of cells in each tissue type by the area of this specific tissue type within the $100-\mu \mathrm{m}$ wide transect, and expressed as cell number per micrometers squared. On each image, we analyzed the region of interest near the midvein $(\mathrm{C} 1$ for ungalled control tissues or G1 - the gall-for galled tissues) and another zone between the midvein and the leaf margin as an internal control (C2 for ungalled control tissues or G2 for galled tissues) (see Figs. 2b and 3b).

For morphometric analyses in C1 (control, see Fig. 2b, c) and G1 (gall, see Fig. 3b, c) zones, we focused on the upper epidermis, palisade parenchyma, and first half of the spongy parenchyma (upper/adaxial portion) as it is closest to the gall interior in which the fundatrix and nymphs feed. Morphometric data is therefore unavailable for the second half of the spongy parenchyma (lower/abaxial portion) and the lower epidermis.

Ninety-eight cells from electron micrographs of 13 samples ( $N=5$ for controls and $N=8$ for galls) were acquired from $\mathrm{C} 1$ (control, see Fig. 2b, c) and G1 (gall, see Fig. 3b, c) zones only and used for cell morphometry (length, width, area, and number of cells and organelles: nucleus, nucleolus, vacuoles, chloroplasts, mitochondria, and starch granules and lipid droplets). Only cell and organelle numbers and average sizes (area expressed as $\mu \mathrm{m}^{2}$ ) are presented here. Ratios between nucleus and cell size, as well as between nucleolus and nucleus were calculated from cell and organelle areas. TEM images taken included upper epidermis, palisade parenchyma, and the first few layers of the spongy parenchyma (upper/adaxial portion) of $\mathrm{C} 1$ and $\mathrm{G} 1$ zones. Thin sections were not taken of the second half of the spongy parenchyma (lower/abaxial portion) or the lower epidermis.

Cell organelles, starch granules, and lipid droplets were identified according to the literature (Bronner 1992; Oliveira et al. 2010, 2011; Vecchi et al. 2013; Carneiro and Isaias 2015a). Nutrient contents (starch granules and lipid droplets) of each analyzed cell were estimated by summing the area of each nutrient allowing comparison between ungalled control and galled tissues for each tissue type.

\section{Statistical analyses}

Statistical analyses were performed using $\mathrm{R}$ version 2.13.1 and RStudio version 0.98.1103 (The R Foundation for Statistical Computing, Vienna, Austria). Cell number and density in C1, C2, G1, and G2 zones (see Figs. 2b and 3b) were compared using either one-way ANOVA or the KruskalWallis tests, depending on whether the data for the specific comparison had a normal or non-normal distribution). Where significant effects were observed, post hoc comparisons were performed using Tukey HSD test and Mann-Whitney test with Bonferroni correction, depending on the normality of the data. Cell number is presented as cell number per tissue type in a $100-\mu \mathrm{m}$ wide transect and cell density as cell number per micrometers squared for each tissue type in the $100-\mu \mathrm{m}$ transect (average \pm S.E.M.). Lengths, widths, and areas of cells and organelles and total areas of starch granules and lipid droplets in ungalled control (zone C1, see Fig. 2b, c) and galled (zone G1, see Fig. 3b, c) tissues (Table 1) were compared using Student and Welch $t$ test (normal distribution) and Mann-Whitney test (non-normal distribution). The level of significance used in all tests was $p$ value $\leq 0.05$. All measurements are presented as micrometers and areas as micrometers squared (average \pm S.E.M.).

\section{Results}

\section{Morphology of ungalled and galled tissues}

From the adaxial surface to the abaxial surface, ungalled leaves $(36.58 \pm 0.78 \mathrm{~mm}$ long and $10.85 \pm 0.26 \mathrm{~mm}$ wide; Fig. 2a) typically had a single cell layer of upper epidermis, two cell layers of palisade parenchyma with small intercellular spaces, three "layers" of spongy parenchyma (about twice as thick as the palisade parenchyma) with large intercellular spaces, and a single layer of lower epidermis in $\mathrm{C} 1$ and $\mathrm{C} 2$ zones (Fig. 2b, c).

On galled leaves (galls $5.96 \pm 0.65 \mathrm{~mm}$ long, 1.73 $\pm 0.27 \mathrm{~mm}$ wide, and $1.41 \pm 0.12 \mathrm{~mm}$ deep; Fig. $3 \mathrm{a}$ ), leaf tissue on one side of the midvein was folded toward the center of the 

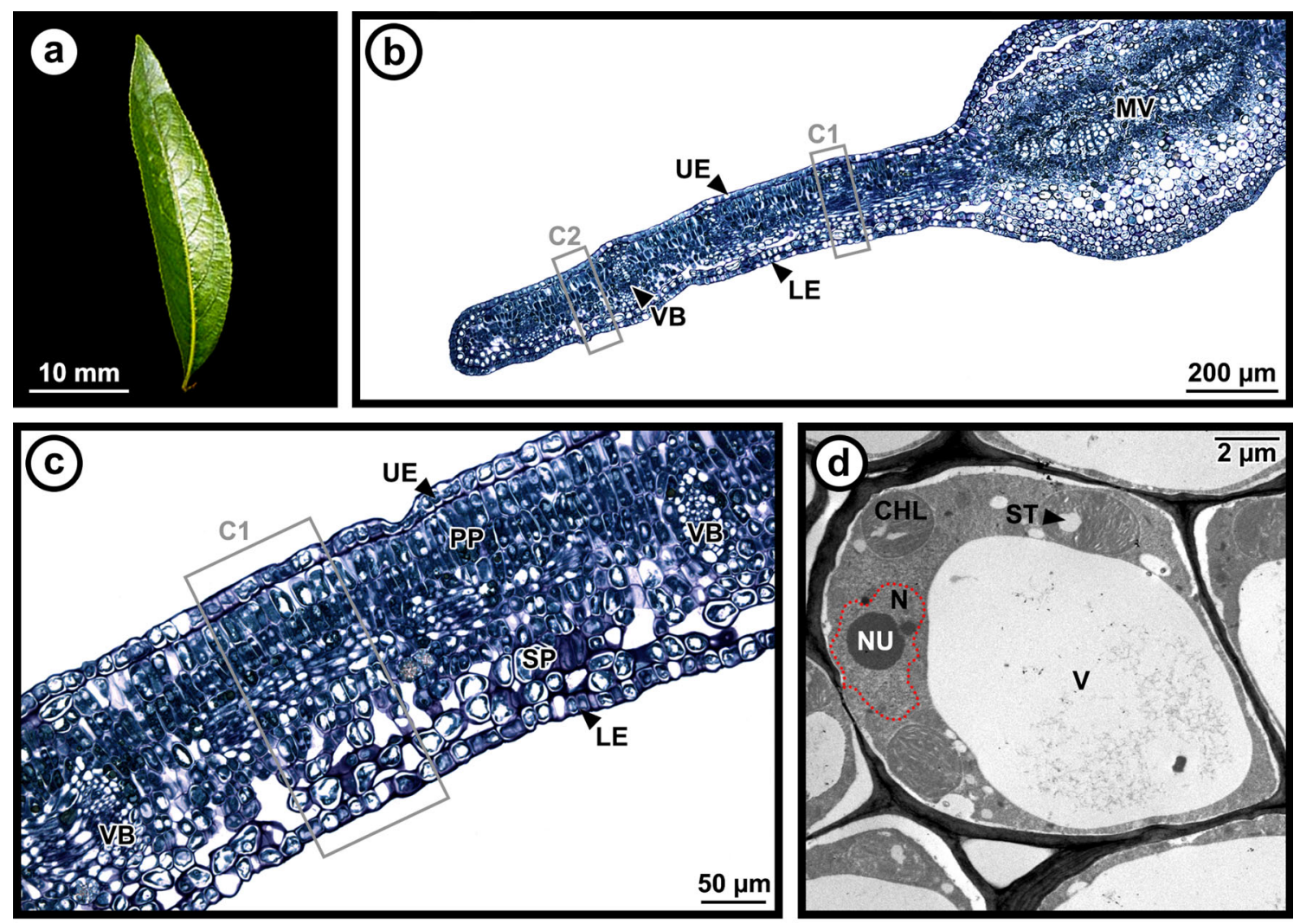

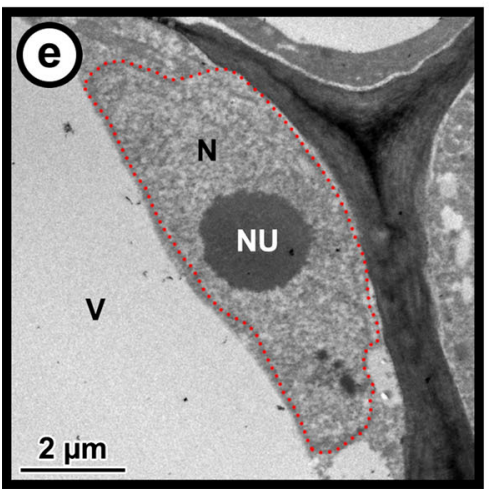

Fig. 2 Morphology of ungalled control poplar Populus angustifolia leaves. Ungalled leaf (a). The unaltered leaf $(\mathbf{b}, \mathbf{c})$ has one layer of upper epidermis, two layers of palisade parenchyma, spongy parenchyma with large intercellular spaces, and one layer of lower epidermis. Cells generally contain only one large vacuole (d), a nucleus, and a visible nucleolus (e), intact chloroplasts (f), and functional vascular bundles $(\mathbf{g}) . \mathrm{C} 1=$ region of interest for cell counts on ungalled control tissues, $\mathrm{C} 2=$ internal control for cell counts on ungalled control tissues. The red dotted line outlines the nucleus. False

leaf and then back to create a fold on the abaxial side of the leaf (Figs. 1 and 3b). In the G1 zone, periclinal and anticlinal cell division was evident between the palisade layer and spongy parenchyma, effectively eliminating intercellular spaces from the spongy parenchyma (Fig. 3c). Cells on the adaxial surface of the G1 zone were more numerous and smaller than cells near the abaxial surface were (density $0.00820 \mathrm{cell} / \mu^{2}{ }^{2}$ in the upper epidermis vs. $0.00496 \mathrm{cell} /$ colors: red $=$ xylem, green $=$ phloem, yellow $=$ bundle sheath cells. T.E.M. images $(\mathbf{d}, \mathbf{e}, \mathbf{f})$ from the spongy parenchyma of the $\mathrm{C} 1$ region, with the exception of vascular bundles (g) that are from a secondary vein in the palisade parenchyma of the $\mathrm{C} 1$ region. $B S H$ bundle sheath cells, $C H L$ chloroplast, $L E$ lower epidermis, $M V$ midvein with vascular bundles, $N$ nucleus, $N U$ nucleolus, $P H$ phloem, $P P$ palisade parenchyma, $S P$ spongy parenchyma, $S T$ starch, $U E$ upper epidermis, $V$ vacuole, $V B$ vascular bundle, $X$ xylem

$\mu \mathrm{m}^{2}$ in the lower epidermis; Welch $t$ test, $p$ value $=0.002$ ) (Figs. 2c, 3c, and 4ab, Table 1), creating the large fold that surrounded the insect.

The leaf was thicker in the gall $(\mathrm{G} 1=312.34 \pm 9.05 \mu \mathrm{m})$ than in the control zone on the same leaf $(\mathrm{G} 2=239.97$ $\pm 10.40 \mu \mathrm{m}$; Mann-Whitney post hoc test with Bonferroni correction, $p$ value $<0.001$; Fig. $3 \mathrm{~b}$ ), whereas the control regions on ungalled leaves, $\mathrm{C} 1$ and $\mathrm{C} 2$, did not differ 

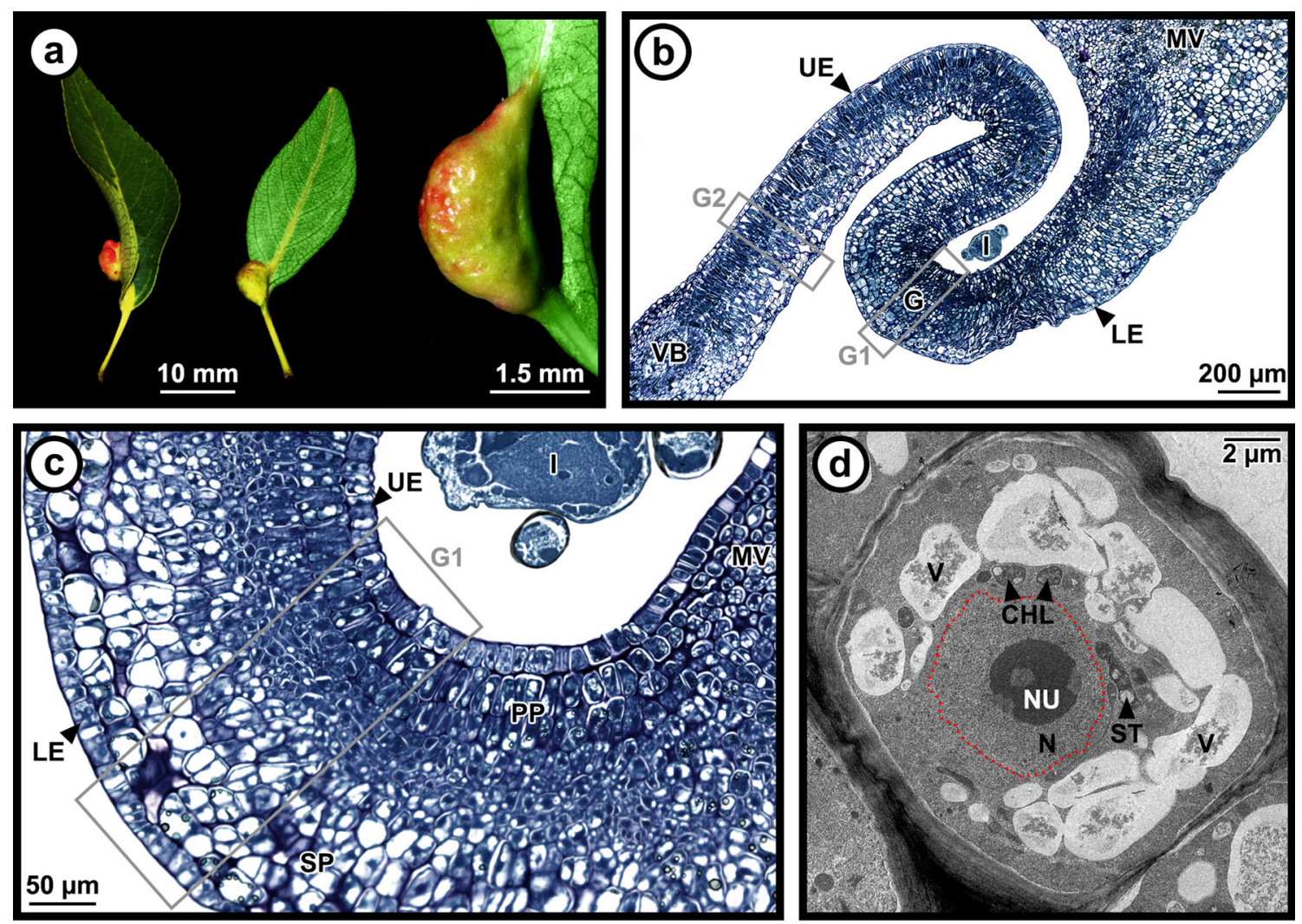

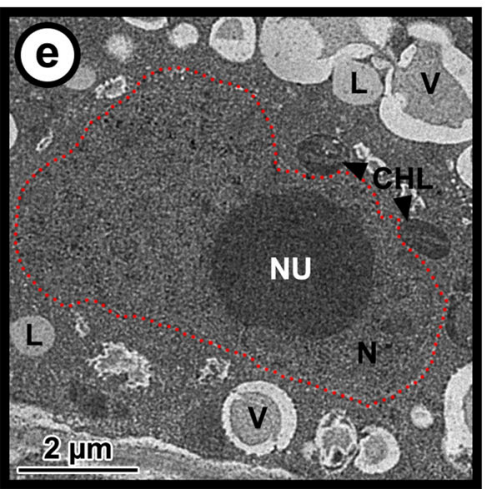

Fig. 3 Morphology of young galls induced by Pemphigus betae on poplar Populus angustifolia leaves. Galled leaves (a) viewed from the upper/adaxial surface (left) and the lower/abaxial surface (center) of the leaf, as well as a gall viewed from the side (right). Leaf tissue on one side of the midvein bends towards the center of the leaf and then back to create a fold that surrounds the aphid on the abaxial side of the leaf (b). The fold then grows abaxially through periclinal and anticlinal divisions, effectively eliminating intercellular spaces from the spongy parenchyma (c). Cells on the adaxial surface are more numerous and smaller than cells near the abaxial surface are, creating the large fold that surrounds the insect. The insect induces altered cells within the gall. In galled tissues, cells (d) are generally smaller, with reduced and fragmented vacuoles,

$(\mathrm{C} 1=207.50 \pm 5.25 \mu \mathrm{m}, \mathrm{C} 2=207.37 \pm 6.67 \mu \mathrm{m} ;$ MannWhitney post hoc test with Bonferroni correction, $p$ val$\mathrm{ue}=0.442$; Fig. 2b). The largest difference in thickness between ungalled control and galled tissues came from the spongy parenchyma which exhibited a $+104.39 \%$ increase in the gall. In galled tissues, cell size and density varied with larger nucleoli and nuclei (e), and smaller and more numerous chloroplasts (f) than their ungalled tissue counterparts (see Fig. 2). Vascular bundles (g) are comprised solely of phloem. G1 = region of interest for cell counts on galled tissues, G2 = internal control for cell counts on galled tissues. The red dotted line outlines the nucleus. False colors: green $=$ phloem. T.E.M. images $(\mathbf{d}, \mathbf{e}, \mathbf{f})$ are all taken in the spongy parenchyma of the G1 region, except images of vascular bundles (g) that have been taken on a secondary vein in the palisade parenchyma of the G1 region. $C H L$ chloroplast, $G$ gall, $I$ insect, $L$ lipid, $L E$ lower epidermis, $M V$ midvein, $N$ nucleus, $N U$ nucleolus, $P H$ phloem, $P P$ palisade parenchyma, $S P$ spongy parenchyma, $S T$ starch, $U E$ upper epidermis, $V$ vacuole, $V B$ vascular bundle

cell type (Figs. 2b, c, 3b, c, and 4a; Table 1). The cell density was higher for the upper epidermis and the palisade parenchyma and lower for the spongy parenchyma and the lower epidermis compared to the control (Tukey HSD post hoc test and Mann-Whitney post hoc test with Bonferroni correction, $p$ value $<0.05$ ) (Fig. 4b). Two different regions can be 
Table 1 Morphometric measurements and counts of cells and organelles

\begin{tabular}{|c|c|c|c|c|}
\hline & Control & Gall & Control & Gall \\
\hline Cell & Average size $\left(\mu \mathrm{m}^{2}\right)$ & & & \\
\hline UE & $163.69 \pm 17.92 \mathrm{a}$ & $94.61 \pm 9.52 b$ & & \\
\hline PP & $154.16 \pm 13.68 \mathrm{a}$ & $130.04 \pm 15.29 b$ & & \\
\hline SP & $219.16 \pm 14.97 \mathrm{a}$ & $183.56 \pm 11.39 \mathrm{~b}$ & & \\
\hline Nucleus & Average size $\left(\mu \mathrm{m}^{2}\right)$ & & Ratio nucleus/cell & \\
\hline UE & $10.92 \pm 1.99 \mathrm{a}$ & $15.82 \pm 1.74 \mathrm{a}$ & $0.07 \pm 0.01 \mathrm{a}$ & $0.17 \pm 0.02 b$ \\
\hline PP & $15.95 \pm 2.83 \mathrm{a}$ & $19.79 \pm 2.55 \mathrm{a}$ & $0.09 \pm 0.01 \mathrm{a}$ & $0.15 \pm 0.02 b$ \\
\hline SP & $11.99 \pm 3.63 \mathrm{a}$ & $16.38 \pm 1.91 \mathrm{a}$ & $0.06 \pm 0.02 \mathrm{a}$ & $0.10 \pm 0.01 \mathrm{a}$ \\
\hline Nucleolus & Average size $\left(\mu \mathrm{m}^{2}\right)$ & & Ratio nucleolus/nuc & \\
\hline UE & $2.75 \pm 0.71 \mathrm{a}$ & $4.04 \pm 0.46 \mathrm{a}$ & $0.20 \pm 0.03 \mathrm{a}$ & $0.23 \pm 0.02 \mathrm{a}$ \\
\hline PP & $5.57 \pm 1.00 \mathrm{a}$ & $3.06 \pm 0.62 \mathrm{a}$ & $0.30 \pm 0.05 \mathrm{a}$ & $0.19 \pm 0.02 b$ \\
\hline SP & $1.70 \pm 0.59 \mathrm{a}$ & $4.80 \pm 0.75 \mathrm{a}$ & $0.27 \pm 0.12 \mathrm{a}$ & $0.33 \pm 0.04 \mathrm{a}$ \\
\hline Vacuole & Average size $\left(\mu \mathrm{m}^{2}\right)$ & & Number/cell & \\
\hline UE & $19.91 \pm 5.81 \mathrm{a}$ & $2.78 \pm 0.43 \mathrm{a}$ & $6.00 \pm 1.15 \mathrm{a}$ & $13.42 \pm 1.06 \mathrm{~b}$ \\
\hline $\mathrm{PP}$ & $22.96 \pm 5.81 \mathrm{a}$ & $4.20 \pm 0.76 b$ & $5.29 \pm 0.97 \mathrm{a}$ & $11.41 \pm 0.97 \mathrm{~b}$ \\
\hline SP & $75.69 \pm 20.84 a$ & $20.07 \pm 4.31 \mathrm{~b}$ & $2.82 \pm 0.80 \mathrm{a}$ & $6.24 \pm 1.59 \mathrm{a}$ \\
\hline Mitochondrion & Average size $\left(\mu \mathrm{m}^{2}\right)$ & & Number/cell & \\
\hline UE & $0.15 \pm 0.02 \mathrm{a}$ & $0.13 \pm 0.02 \mathrm{a}$ & $2.75 \pm 0.85 \mathrm{a}$ & $3.00 \pm 1.13 \mathrm{a}$ \\
\hline $\mathrm{PP}$ & $0.18 \pm 0.04 \mathrm{a}$ & $0.33 \pm 0.10 \mathrm{a}$ & $2.00 \pm 0.58 \mathrm{a}$ & $1.00 \pm 0.00 \mathrm{a}$ \\
\hline SP & $0.31 \pm 0.03 \mathrm{a}$ & $0.30 \pm 0.07 \mathrm{a}$ & $6.60 \pm 2.06 \mathrm{a}$ & $2.00 \pm 0.00 \mathrm{a}$ \\
\hline Chloroplast & Average size $\left(\mu \mathrm{m}^{2}\right)$ & & Number/cell & \\
\hline UE & $0.81 \pm 0.12 \mathrm{a}$ & $0.58 \pm 0.04 \mathrm{a}$ & $3.91 \pm 0.92 \mathrm{a}$ & $8.22 \pm 1.39 b$ \\
\hline PP & $2.33 \pm 0.19 \mathrm{a}$ & $1.18 \pm 0.06 b$ & $6.23 \pm 0.87 \mathrm{a}$ & $11.85 \pm 1.61 b$ \\
\hline SP & $2.55 \pm 0.19 \mathrm{a}$ & $1.32 \pm 0.09 b$ & $10.40 \pm 2.69 \mathrm{a}$ & $6.17 \pm 0.97 \mathrm{a}$ \\
\hline Starch & Total area $\left(\mu \mathrm{m}^{2}\right)$ & & & \\
\hline UE & $0.17 \pm 0.00 \mathrm{a}$ & $0.56 \pm 0.14 \mathrm{a}$ & & \\
\hline $\mathrm{PP}$ & $0.24 \pm 0.14 \mathrm{a}$ & $2.13 \pm 0.89 \mathrm{a}$ & & \\
\hline SP & $0.73 \pm 0.34 \mathrm{a}$ & $2.33 \pm 0.56 b$ & & \\
\hline Lipid & Total area $\left(\mu \mathrm{m}^{2}\right)$ & & & \\
\hline UE & $0.56 \pm 0.19 \mathrm{a}$ & $2.54 \pm 1.08 \mathrm{a}$ & & \\
\hline PP & $0.58 \pm 0.10 \mathrm{a}$ & $0.94 \pm 0.23 \mathrm{a}$ & & \\
\hline SP & $0.93 \pm 0.32 \mathrm{a}$ & $1.43 \pm 0.83 b$ & & \\
\hline
\end{tabular}

Measurements and numbers of cells and organelles for each tissue type (upper epidermis, palisade parenchyma, and spongy parenchyma) in ungalled control (zone C1, see Fig. 2b, c) and galled tissues (zone G1, see Fig. 3b, c) from electron micrographs. Statistical differences $(p$ value $\leq 0.05)$ between means for ungalled controls and galls in each tissue type (comparisons between columns: control vs. gall for a same line) are shown by different letters $(\mathrm{a}, \mathrm{b})$. Data shown as average \pm S.E.M

$P P$ palisade parenchyma, $S P$ spongy parenchyma, $U E$ upper epidermis distinguished in the gall: the upper/adaxial portion with cells that are smaller and more numerous, and the lower/abaxial portion with cells that are bigger and less numerous (Fig. 3c).

In ungalled tissues, vascular bundles were comprised of xylem located toward the adaxial side of the leaf with phloem located toward the abaxial side, and the entire bundle was surrounded by bundle sheath cells (Fig. $2 \mathrm{~g}$ ). In galled tissues, the vascular bundles were disorganized; xylem and bundle sheath cells were absent. The stylet pathway between parenchyma cells to reach the phloem was not observed on the sections of the galls that were analyzed for this study.
Phloem sieve tube elements and companion cells were more numerous and larger in galled tissues than in ungalled tissues (Figs. $2 \mathrm{~g}$ and $3 \mathrm{~g}$ ).

\section{Morphometry of cells and organelles in ungalled and galled tissues}

Nuclei, as well as nucleoli, in the galls and controls were of the same size (Figs. 2d, e and 3d, e, Table 1); however, cells were smaller in the gall (upper epidermis, palisade parenchyma, upper/adaxial portion of the spongy parenchyma), leading to 
Fig. 4 Cell numbers and densities. Cell numbers (a) and densities (b) for each tissue type in ungalled controls and galls from light micrographs. Statistical differences $(p$ value $\leq 0.05$ ) between means for ungalled controls and galls in each tissue type are shown by different letters $(\mathbf{a}, \mathbf{b})$. Data shown as average \pm S.E.M. $\mathrm{C} 1=$ region of interest for cell counts on ungalled control tissues, $\mathrm{C} 2=$ internal control for cell counts on ungalled control tissues, $\mathrm{G} 1=$ region of interest for cell counts on galled tissues, $\mathrm{G} 2=$ internal control for cell counts on galled tissues (see Figs. $2 \mathrm{~b}$ and $3 \mathrm{~b}$ ). $L E$ lower epidermis, $P P$ palisade parenchyma, $S P$ spongy parenchyma, $U E$ upper epidermis, $V B$ vascular bundle
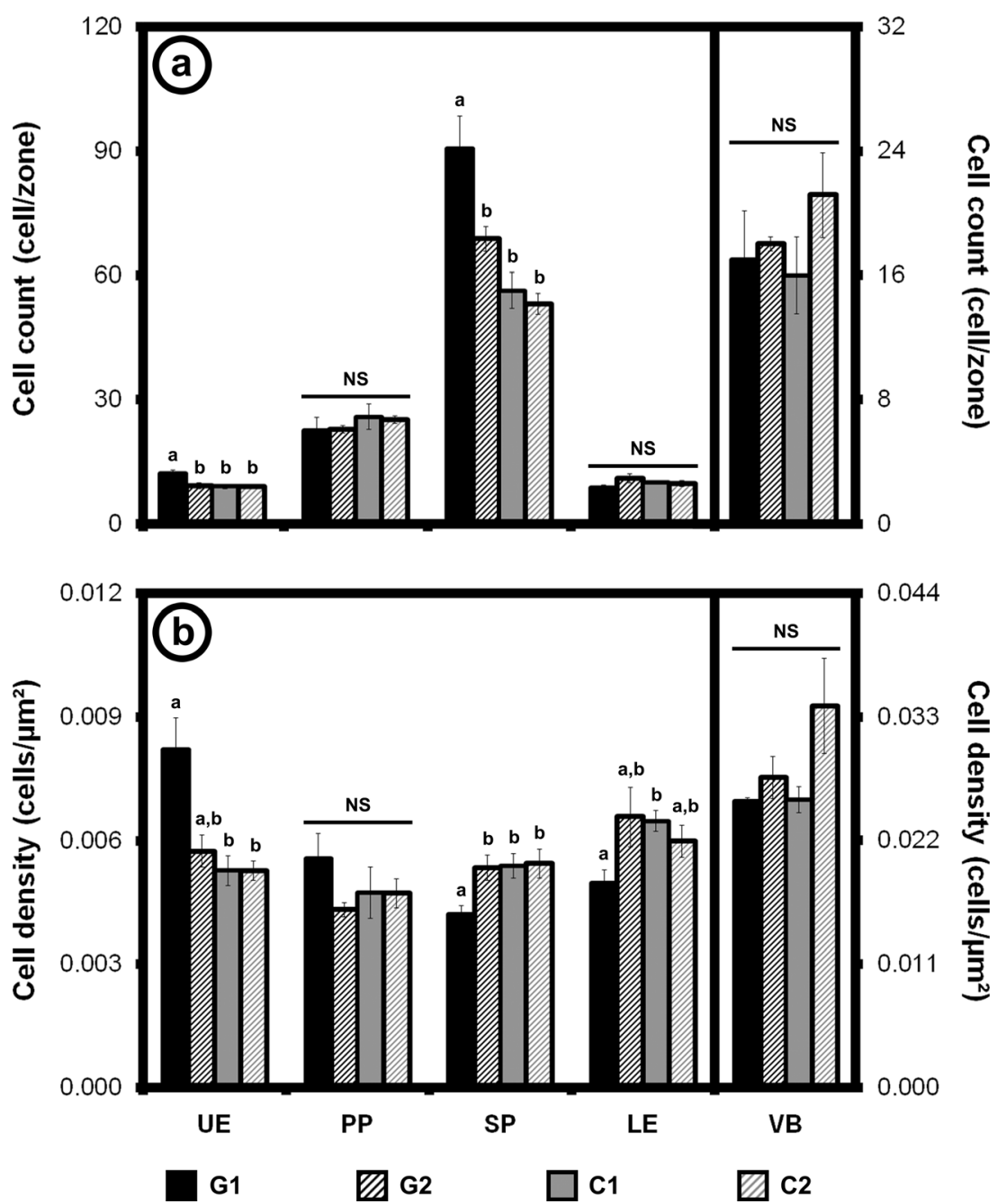

a higher ratio between the nuclei and their respective cells in the upper epidermis and palisade parenchyma (Figs. 2e and 3 e, Table 1). Mitochondria size was also similar in galls and controls. Vacuoles were reduced and fragmented in cells from each tissue type of galled tissues but were intact and of normal size in ungalled tissues (Figs. $2 \mathrm{~d}$ and $3 \mathrm{~d}$, Table 1). Chloroplasts were smaller in the gall than in the control tissues, especially in the palisade and spongy parenchyma. Chloroplasts were also more numerous in the upper epidermis and palisade parenchyma but tended to be less numerous in the spongy parenchyma (Table 1). Electron microscopy revealed that chloroplasts in the control tissues had normal grana with flattened thylakoid membranes and a more rounded shape, whereas chloroplasts in galled tissues are smaller, had degraded, having lost their round shape and organization, and exhibited underdeveloped lamellation, disorganized grana stacks, and swollen thylakoids (Figs. 2f and 3f).

Starch content, as estimated by structural features, was 310-fold higher in all of the galled tissues compared to all of their respective control tissues, although the difference was only statistically significant in the spongy parenchyma
(Table 1). Cells in the palisade and spongy parenchyma contained more starch than those in the upper epidermis did (Figs. $2 \mathrm{f}$ and $3 \mathrm{f}$, Table 1). Lipid content, as estimated by structural features, also tended to be greater in all of the galled tissues (Table 1).

\section{Discussion}

The morphological analysis of $P$. betae galls performed in this study describes for the first time how this insect alters leaf morphology and structure (Fig. 1) to create a leaf fold gall (Rohfritsch 1992) and quantifies of the extent of the modifications. The fundatrices insert their stylet between cells into the leaf tissue on one side of the midvein to reach the phloem sap from vascular bundles in the first few layers of spongy parenchyma of the gall (Fig. 1, step 1). As a result, growth is arrested at the stylet insertion site, a small depression forms, and the petiole bends toward the center and then back again to create the gall (Fig. 1, steps 2 and 3). Growth continues as normal on the opposite side of the petiole. The tissue changes 
in the galled leaf were caused by tissue hyperplasia (more numerous cells) in the upper/adaxial portion of the mesophyll and cell hypertrophy (bigger cells) in the lower/abaxial portion of the gall (Figs. 3c and 5). Growth via tissue hyperplasia and cell hypertrophy is a common feature in galls and pseudogalls (when the insect is not enclosed within plant tissue, i.e., open galls; Zhang and Chen 1999) induced by different aphids and relatives such as Phloeomyzus passerinii, Eriosoma lanigerum, Adelges laricis, Adelges abietis, and Daktulosphaira vitifoliae, but also in other insect-induced galls in general (Elzen 1983; Brown et al. 1991; Rohfritsch and Anthony 1992; Wool and Bar-El 1995; Forneck et al. 2002; Kraus et al. 2002; Arduin et al. 2005; Álvarez et al. 2009; Oliveira and Isaias 2010a; Carneiro et al. 2014; Dardeau et al. 2014a, b; Tooker and Helms 2014; Carneiro et al. 2015; Kurzfeld-Zexer et al. 2015; Suzuki et al. 2015). Cell divisions occur in several planes, increasing the number of cell layers and the thickness of the parenchyma, and are related to the new functions of the mesophyll as a feeding site and a protective barrier for the insect (Mani 1964; Rohfritsch 1992; Moura et al. 2008; Dias et al. 2013; Carneiro et al. 2015).

As phloem-feeders, aphids must have access to the vascular system of the host plant or induce the formation of new vascular elements at the galling sites as in galls induced by Geoica wertheimae aphids (Wool et al. 1999; Wool 2005). The modified structure of vascular bundles observed in this study is a key feature of gall development. The absence of xylem and bundle sheath cells may facilitate the aphid's access to its nutrient source in the phloem, thus eliminating the need for stylet penetration into or around these cells (Figs. $3 \mathrm{~g}$ and 4b). Many galling insects induce and feed on a nutritive layer within the gall that accumulates nutrients. As with other aphids and psyllids, $P$. betae feed directly from the phloem and therefore no true nutritive tissue was expected to develop (Bronner 1992; Álvarez et al. 2009; Álvarez 2011; Kurzfeld-Zexer et al. 2015). However, P. betae does affect the size and shape of cells and organelles, some of which exhibit features typical of nutritive cells induced by other galling insects and root-knot nematodes, including a conspicuous nucleolus, a fragmented vacuole, smaller and degraded chloroplasts, and a dense cytoplasm (Jones and Payne 1978; Bronner 1992; Isaias and Oliveira 2012; Rodiuc et al. 2014). We refer here to those morphological changes as nutritive-like because they do not include the larger nucleus and more numerous mitochondria present in true nutritive layers (Fig. 5).

Cytological and histochemical gradients have also been reported in galls induced by other sucking insects, such as in galls induced by two psyllid species, Euphalerus ostreoides and Nothotrioza cattleiani, and three aphid species, Paracletus cimiciformis, Forda marginata, and Forda formicaria, (Álvarez et al. 2009; Oliveira and Isaias 2010b; Isaias and Oliveira 2012; Carneiro and Isaias 2015a, b). In the first stages of gall development we examined, cells exhibited large nuclei resembling those reported for metabolically active cells in the nutritive tissues of galls induced by Thysanoptera (Raman and Ananthakrishnan 1983; Carneiro and Isaias 2015a). Another feature of nutritive tissue is starch accumulation in the vicinity of hypertrophied cells, which provides soluble sugars to the insect (Bronner 1992; Rohfritsch and Anthony 1992; Forneck et al. 2002). An accumulation of nutrients (starches and to a lesser extent lipids) also occurs in the

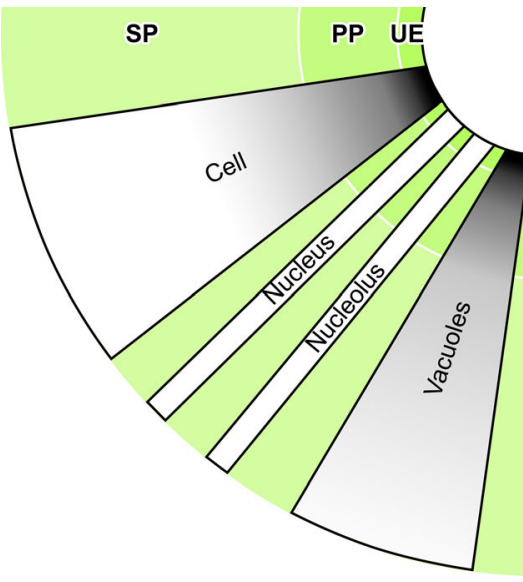

Fig. 5 Representation of metabolic activities and cell/organelle size and shape within the nutritive tissues of Pemphigus galls. Average size of the cells/organelles in each tissue is represented by the width of the ray, and the gradient of the number/density is represented by shading. Wider areas are indicative of larger cells, organelles, and nutrients while thinner areas are indicative of smaller ones. Darker shades of gray are equivalent to higher numbers/densities, while lighter shades of gray are equivalent to

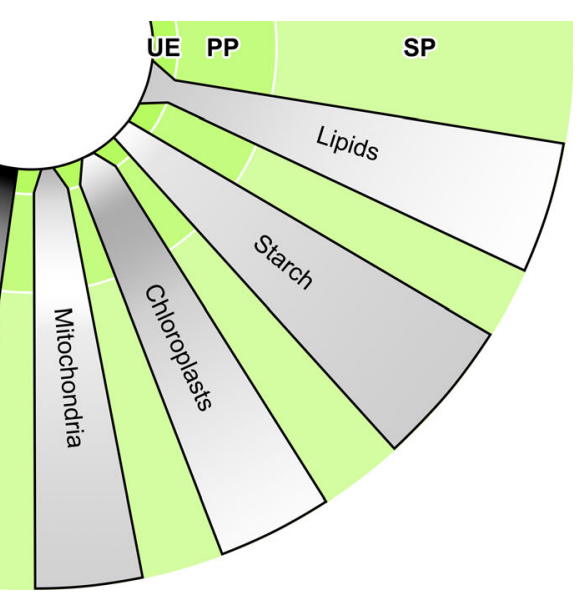

lower numbers/densities of cells, organelles, and nutrients. Different averages do not necessarily reflect statistically significant differences (see Fig. 4 and Table 1 for statistical analysis). Shape and color are relative to the item they represent and not to be compared with others. The green background represents the gall. $P P$ palisade parenchyma, $S P$ spongy parenchyma, UE upper epidermis. Adapted from Bronner (1992) 
palisade and first few layers of spongy parenchyma of the $P$. betae gall but not to the extent as that observed in nutritive cells of galls induced by Cecidomyiidae, Cynipidae, and a microlepidopteran species (Bronner 1992; Rohfritsch 1992; Oliveira et al. 2010; Vecchi et al. 2013). Larson and Whitham (1991) used ${ }^{14} \mathrm{C}$-labeling experiments to characterize the alteration of the source-sink translocation patterns in poplar infected by $P$. betae aphids. This study showed that $P$. betae galls function as physiological sinks, drawing in resources from the surrounding plant tissue (galled and surrounding leaves) leading to an accumulation of nutrients at the feeding site. The imported nutrients improve the nutritional quality of phloem sap and accumulate in the most internal cell layers (Larson and Whitham 1991; Inbar et al. 1995; Fay et al. 1996; Koyama et al. 2004; Suzuki et al. 2009; Dias et al. 2013). Thus, even though the Pemphigus aphids do not consume the gall tissue, they induce changes in the plant vascular system that lead to nutrient accumulation in surrounding galled tissues. The capacity of aphids to alter the host plant to create food sources of a higher quality than in ungalled plants likely enables the hundreds of offspring to feed for several weeks in a small and confined space before dispersion (Larson and Whitham 1991; Wool et al. 1998; Isaias and Oliveira 2012). Indeed, Larson and Whitham (1991) showed that aphids respond to the increasing food demands of a growing colony in mature galls by importing more resources from neighboring leaves. It appears that the galling aphid effectively manipulates plant morphogenesis to produce new cell fates that increase the adaptive value of the gall structure (Stone and Schönrogge 2003; Carneiro and Isaias 2015a).

\section{Conclusion}

$P$. betae feeding on the narrowleaf cottonwood $P$. angustifolia induces of a leaf fold gall formation. In the first stages of gall development, we observed cell hyperplasia and hypertrophy, consistent with a model of gall formation by alteration of insect-induced or insect-supplied phytohormones. The long and intimate relationship of endophagous feeding insects with their host plants likely facilitates biochemical and hormonal crosstalk between insects and plants, resulting in host plant manipulation by insects (Schultz 2002; Schultz and Appel 2004; Body et al. 2013; Giron et al. 2013, 2015; Giron and Glevarec 2014; Robischon 2015). Whether homologous or convergent, shared signaling systems provide herbivores with the ability to generate optimal microenvironments for growth, survival, and reproduction.

Acknowledgments This project was supported in part by a grant to the University of Missouri from the Howard Hughes Medical Institute Precollege and Undergraduate Science Education Program \#52006953 to JCS and NSF IOS \#1256552 to JCS and HMA. We would like to thank
Tom Whitham for his advice on gall ontogeny and for providing access to the field site and Matt Zinkgraf and Art Keith for facilitating collecting there. We also thank Arpine Mikayelyan and Aleksandr Jurkevic from the Molecular Cytology Core (University of Missouri, Columbia MO, USA), Tommi A. White and DeAna Grant from the Electron Microscopy Core (University of Missouri, Columbia MO, USA), and Janet Adair and Jill Hansen from IDEXX Radil (BioResearch Laboratory, Columbia MO, USA) for all of their help. Last, we thank two anonymous reviewers whose comments significantly improved the previous version of the manuscript.

Author contributions $\quad$ RR, HA, and JS designed the overall study. RR carried out the microscopy, supervised by MW, RR and MB analyzed the micrographs. The interpretation and writing drafts were done by RR, MB, HA, and JS, with help from MW.

\section{Compliance with ethical standards}

Conflict of interest The authors declare that there is no conflict of interest.

Open Access This article is distributed under the terms of the Creative Commons Attribution 4.0 International License (http:// creativecommons.org/licenses/by/4.0/), which permits unrestricted use, distribution, and reproduction in any medium, provided you give appropriate credit to the original author(s) and the source, provide a link to the Creative Commons license, and indicate if changes were made.

\section{References}

Allison SD, Schultz JC (2005) Biochemical responses of chestnut oak to a galling cynipid. J Chem Ecol 31:151-166. doi:10.1007/s10886005-0981-5

Álvarez R (2011) Microscopic study of the walls of galls induced by Geoica utricularia and Baizongia pistaciae in Pistacia terebinthus: a contribution to the phylogeny of Fordini. Arthropod Plant Interact 6:137-145. doi:10.1007/s11829-011-9154-3

Álvarez R, Encina A, Pérez Hidalso N (2009) Histological aspects of three Pistacia terebinthus galls induced by three different aphids: Paracletus cimiciformis, Forda marginata and Forta formicaria. Plant Sci 176:133-144. doi:10.1016/j.plantsci.2008.11.006

Arduin M, Fernandes GW, Krau JE (2005) Morphogenesis of galls induced by Baccharopelma dracunculifoliae (Hemiptera: Psyllidae) on Baccharis dracunculifolia (Asteraceae) leaves. Braz J Biol 65: 559-571. doi:10.1590/S1519-69842005000400002

Body M, Kaiser W, Dubreuil G, Casas J, Giron D (2013) Leaf-miners coopt microorganisms to enhance their nutritional environment. J Chem Ecol 39:969-977. doi:10.1007/s10886-013-0307-y

Bronner R (1992) The role of nutritive cells in the nutrition of cynipids and cecidomyiids. In: Shorthouse JD, Rohfritsch O (eds) Biology of insect induced galls. Oxford University Press, New York, pp 118140

Brown MW, Glenn DM, Wisniewski ME (1991) Functional and anatomical disruption of apple roots by the woolly apple aphid (Homoptera: Aphididae). J Econ Entomol 84:1823-1826

Carneiro RGS, Isaias RMS (2015a) Cytological cycles and fates in Psidium myrtoides are altered towards new cell metabolism and functionalities by the galling activity of Nothotrioza myrtoidis. Protoplasma 252:637-646. doi:10.1007/s00709-014-0709-x

Carneiro RGS, Isaias RMS (2015b) Gradients of metabolite accumulation and redifferentiation of nutritive cells associated with vascular 
tissues in galls induced by sucking insects. AoB Plants 7, plv086. doi:10.1093/aobpla/plv086

Carneiro RGS, Oliveira DC, Isaias RMS (2014) Developmental anatomy and immunocytochemistry reveal the neo-ontogenesis of the leaf tissues of Psidium myrtoides (Myrtaceae) towards the globoid galls of Nothotrioza myrtoidis (Triozidae). Plant Cell Rep 33:2093-2106. doi:10.1007/s00299-014-1683-7

Carneiro RGS, Pacheco P, Isaias RMS (2015) Could the extended phenotype extend to the cellular and subcellular levels in insect-induced galls? Plos ONE 10, e0129331. doi:10.1371/journal.pone.0129331

Castro ACR, Leite GLD, Oliveira DC, Isaias RMS (2012) Morphological patterns of a hymenopteran gall on the leaflets of Caryocar brasiliense Camb. (Caryocaraceae). Am J Plant Sci 3:921-929. doi:10.4236/ajps.2012.37109

Chapman RF (2013) Chapter 2: Mouthparts and feeding. In: The insects: Structure and function. Cambridge University Press. 961 pages

Chen MS, Liu X, Yang Z, Zhao H, Shukle RH, Stuart JJ, Hulbert S (2010) Unusual conservation among genes encoding small secreted salivary gland proteins from a gall midge. BMC Evol Biol 10:296. doi:10.1186/1471-2148-10-296

Compson ZG, Larson KC, Zinkgraf MS, Whitham TG (2011) A genetic basis for the manipulation of sink-source relationships by the galling aphid Pemphigus betae. Oecologia 167:711-721. doi:10.1007/ s00442-011-2033-x

Cornell HV (1983) The secondary chemistry and complex morphology of galls formed by the Cynipinae. Why and how? Am Midl Nat 110: 225-234

Crespi B, Worobey M (1998) Comparative analysis of gall morphology in Australian gall thrips: the evolution of extended phenotypes. Evol 52:1686-1696

Dardeau F, Pointeau S, Ameline A, Laurans F, Cherqui A, Lieutier F, Sallé A (2014a) Host manipulation by an herbivore optimizes its feeding behaviour. Anim Behav 95:49-56. doi:10.1016/j.anbehav. 2014.06.002

Dardeau F, Deprost E, Laurans F, Lainé V, Lieutier F, Sallé A (2014b) Resistant poplar genotypes inhibit pseudogall formation by the wooly poplar aphid, Phloeomyzus passerinii Sign. Trees 28:10071019. doi:10.1007/s00468-014-1014-1

Dawkins R (1982) The extended phenotype: the long reach of the gene. Oxford University Press, 313 pages

Diamond SE, Blair CP, Abrahamson WG (2008) Testing the nutrition hypothesis for the adaptive nature of insect galls: does a nonadapted herbivore perform better in galls? Ecol Entomol 33:385393. doi:10.1111/j.1365-2311.2007.00979.x

Dias GG, Ferreira BG, Moreira GRP, Isaias RMS (2013) Developmental pathway from leaves to galls induced by a sap-feeding insect on Schinus polygamus (Cav.) Cabrera (Anacardiaceae). An Acad Bras Cienc 85:187-200. doi:10.1590/S0001-37652013000100010

Dunn JA (1960) The formation of galls by some species of Pemphigus (Homoptera, Aphididae). Marcellia 30:155-167

Elzen G (1983) Cytokinins and insect galls. Comp Biochem Physiol Part A: Physiol 76:17-19

Fay PA, Preszler RW, Whitham TG (1996) The functional resource of a gall-forming adelgid. Oecologia 105:199-204. doi:10.1007/ BF00328547

Forbes AR (1977) The mouthparts and feeding mechanism of aphids. In: Harris K, Maramorosch K (eds) Aphids as virus vectors. Academic Press, New York, pp 83-103

Formiga AT, Isaias RMS (2011) Responses of the host plant tissues to gall induction in Aspidosperma spruceanum Müell. Arg. (Apocynaceae). Am J Plant Sci 2:823-834. doi:10.4236/ajps.2011. 26097

Formiga AT, De Melo Reis Gonçalves SJ, Soares GLG, Isaias RMS (2009) Relationships between phenolic contents and a Cecidomyiidae gall cycle in Aspidosperma spruceanum Müll. Arg.
(Apocynaceae). Acta Bot Bras 23:93-99. doi:10.1590/S010233062009000100012

Formiga AT, Silveira FAO, Fernandes GW, Isaias RMS (2015) Phenotypic plasticity and similarity among gall morphotypes on a superhost, Baccharis reticularia (Asteraceae). Plant Biol 17:512521. doi:10.1111/plb.12232

Forneck A, Kleinmann S, Blaich R (2002) Histochemistry and anatomy of Phylloxera (Daktulosphaira vitifoliae) induced galls (nodosities) on young roots of grape vine (Vitis spp.). Vitis 41:93-97

Giron D, Glevarec G (2014) Cytokinin-induced phenotypes in plantinsect interactions: learning from the bacterial world. J Chem Ecol 40:826-835. doi:10.1007/s10886-014-0466-5

Giron D, Frago E, Glevarec G, Pieterse CMJ, Dicke M (2013) Cytokinins as key regulators in plant-microbe-insect interactions: connecting plant growth and defence. Funct Ecol 27:599-609. doi:10.1111/ 1365-2435.12042

Giron D, Huguet E, Stone GN, Body M (2015) Insect-induced effects on plants and possible effectors used by galling and leaf-mining insects to manipulate their host-plant. J Insect Physiol. doi:10.1016/j. jinsphys.2015.12.009

Harper AM (1959) Gall aphids on poplar in Alberta. I. Descriptions of galls and distributions of aphids. Can Entomol 91:489-496. doi:10. 4039/Ent91489-8

Hartley SE (1998) The chemical composition of plant galls: are levels of nutrients and secondary compounds controlled by the gall-former? Oecologia 113:492-501. doi:10.1007/s004420050401

Hartley SE, Lawton JH (1992) Host-plant manipulation by gall-insects: a test of the nutrition hypothesis. J Anim Ecol 61:113-119

Higton RN, Mabberly DJ (1994) A willow gall from the galler's point of view. In: Williams MAJ (ed) Plant Galls - Organisms, Interactions, Populations. Clarendon Press, pp. 301-312

Hogenhout SA, Bos JI (2011) Effector proteins that modulate plant-insect interactions. Curr Opin Plant Biol 14:422-428. doi:10.1016/j.pbi. 2011.05.003

Huang MY, Huang WD, Chou HM, Lin KH, Chen CC, Chen PJ, Chang YT, Yang CM (2014) Leaf-derived cecidomyiid galls are sinks in Machilus thunbergii (Lauraceae) leaves. Physiol Plant 152:475485. doi:10.1111/ppl.12186

Hutchinson WD, Campbell D (1994) Economic impact of sugarbeet root aphid (Homoptera: Aphididae) on sugarbeet yield and quality in southern Minnesota. J Econ Entomol 87:465-475. doi:10.1093/ jee/87.2.465

Ikai N, Hijii N (2007) Manipulation of tannins in oaks by galling cynipids. J For Res 12:316-319. doi:10.1007/s10310-007-0016-x

Imms AD (1947) Insect natural history. Collins, London

Inbar M, Eshel A, Wool D (1995) Interspecific competition among phloem-feeding insects mediated by induced host-plant sinks. Ecology 76:1506-1515. doi:10.2307/1938152

Isaias RMS, Oliveira DC (2012) Chapter 11: Gall phenotypes - Product of plant cells defensive responses to the inducers attack. In: Mérillon JM, Ramawat KG (eds) Plant defence: biological control. Progress in Biological Control, Springer Science 12:273-290

Jones MGK, Payne HL (1978) Early stages of nematode-induced giantcell formation in roots of Impatiens balsamina. J Nematol 10:70-84

Koyama Y, Yao I, Akimoto SI (2004) Aphid galls accumulate high concentrations of amino acids: a support for the nutrition hypothesis for gall formation. Entomol Exp Appl 113:35-44. doi:10.1111/j.00138703.2004.00207.x

Kraus JE, Arduin M, Venturelli M (2002) Anatomy and ontogenesis of hymenopteran leaf galls of Struthanthus vulgaris Mart (Loranthaceae). Rev Bras Bot 25:449-458. doi:10.1590/S010084042002012000009

Kurzfeld-Zexer L, Lev-Yadun S, Inbar M (2015) One aphid species induces three gall types on a single plant: comparative histology of one genotype and multiple extended phenotypes. Flora 210:19-30. doi: 10.1016/j.flora.2014.10.007 
Larson KC, Whitham TG (1991) Manipulation of food resources by a gall-forming aphid: the physiology of sink-source interactions. Oecology 88:15-21. doi:10.1007/BF00328398

Mani MS (1964) Ecology of plant galls. W Junk (ed), The Hague

McManus JFA, Mowry RW (1960) Staining methods, histologic and histochemical. Hoeber Medical Division of Harper and Row, New York, pp 132 and 261

Moran NA (1991) Phenotype fixation and genotypic diversity in the complex life cycle of the aphid Pemphigus betae. Evol 45:957-970

Moran NA, Whitham TG (1988) Population fluctuations in complex life cycles: an example from Pemphigus aphids. Ecol 69:1214-1218. doi: $10.2307 / 1941276$

Motta LB, Kraus JE, Salatino A, Salatino MLF (2005) Distribution of metabolites in galled and non-galled foliar tissues of Tibouchina pulchra. Biochem Syst Ecol 33:971-981. doi:10.1016/j.bse.2005. 02.004

Moura MZD, Soares GLG, Isaias RMS (2008) Species-specific changes in tissue morphogenesis induced by two arthropod leaf gallers in Lantana camara (Verbenaceae). Aust J Bot 56:153-160. doi:10. 1071/BT07131

Muñoz-Viveros AL, Itzhak Martinez J-J, Molist P, González-Sierra S, González Julián P, Álvarez R (2014) Microscopic study of galls induced by three species of Geopemphigus (Hemiptera, Aphididae, Eriosomatinae) on Pistacia mexicana. Arthropod Plant Interact 8:531-538. doi:10.1007/s11829-014-9333-0

Nabity PD, Haus MJ, Berenbaum MR, DeLucia EH (2013) Leaf-galling phylloxera on grapes reprograms host metabolism and morphology. PNAS 110:16663-16668. doi:10.1073/pnas.1220219110

Nakamura M, Miyamoto Y, Ohgushi T (2003) Gall initiation enhances the availability of food resources for herbivorous insects. Funct Ecol 17:851-857. doi:10.1111/j.1365-2435.2003.00786.x

Nyman T, Julkunen-Tiitto R (2000) Manipulation of the phenolic chemistry of willows by gall-inducing sawflies. PNAS 97:13184-13187

Oliveira DC, Isaias RMS (2010a) Redifferentiation of leaflet tissues during midrib gall development in Copaifera langsdorffii (Fabaceae). S Afr J Bot 76:239-248. doi:10.1016/j.sajb.2009.10.011

Oliveira DC, Isaias RMS (2010b) Cytological and histochemical gradients induced by a sucking insect in galls of Aspidosperma australe Arg. Muell (Apocynaceae). Plant Sci 178:350-358. doi:10.1016/j. plantsci.2010.02.002

Oliveira DC, Alves Magalhães T, Gonçalves Silva Carneiro R, Neiva Alvim M, Isaias RMS (2010) Do Cecidomyiidae galls of Aspidosperma spruceanum (Apocynaceae) fit the pre-established cytological and histochemical patterns? Protoplasma 242:81-93. doi:10.1007/s00709-010-0128-6

Oliveira DC, Gonçalves Da Silva Carneiro R, Alves Magalhães T, Isaias RMS (2011) Cytological and histochemical gradients on two Copaifera langsdorffii Desf. (Fabaceae) - Cecidomyiidae gall systems. Protoplasma 248:829-837. doi:10.1007/s00709-010-0258-x

Price PW, Waring GL, Fernandes GW (1987) Adaptive nature of insect galls. Environ Entomol 16:15-24

Raman A, Ananthakrishnan TN (1983) Studies on some thrips (Thysanoptera: Insecta) induced galls. 2. Fine-structure of the nutritive zone. Proc Indian Natl Sci Acad Part B 49:525-561

Redfern M (2011) Plant galls. The new naturalist library. Harper Collins Publishers, London, p 562

Reynolds ES (1963) The use of lead citrate at high $\mathrm{pH}$ as an electronopaque stain in electron microscopy. J Cell Biol 17:208-212. doi:10. 1083/jcb.17.1.208

Robischon M (2015) Do cytokinins function as two-way signals between plants and animals? Bioessays 37:356-363. doi:10.1002/bies. 201400099

Rodiuc N, Vieira P, Banora MY, De Almeida Engler J (2014) On the track of transfer cell formation by specialized plant-parasitic nematodes. Front Plant Sci 5:160. doi:10.3389/fpls.2014.00160
Rohfritsch O (1977) Ultrastructure of the nutritive tissue of the Chermes abietis L. fundatrix on Picea excelsa L. Marcellia 40:135-49

Rohfritsch O (1992) Patterns in gall development. In: Shorthouse JD, Rohfritsch $\mathrm{O}$ (eds) Biology of insect induced galls. Oxford University Press, New York, pp 60-86

Rohfritsch O, Anthony M (1992) Strategies in gall induction by two groups of Homopterans. In: Shorthouse JD, Rohfritsch O (eds) Biology of insects-induced galls. Oxford University Press, New York, pp 102-117

Schoonhoven LM, Van Loon JJA, Dicke M (2005) Insect-plant biology. Oxford University Press. 440 pages

Schultz JC (2002) Shared signals and the potential for phylogenetic espionage between plants and animals. Integr Comp Biol 42:454 462. doi:10.1093/icb/42.3.454

Schultz JC, Appel HM (2004) Cross-kingdom cross-talk: hormones shared by plants and their insect herbivores. Ecol 85:70-77. doi: 10.1890/02-0704

Shorthouse JD, Rohfritsch O (1992) Biology of insect induced galls. Oxford University Press, New York

Shorthouse JD, Wool D, Raman A (2005) Gall-inducing insects-nature's most sophisticated herbivores. Basic Appl Ecol 6:407-411. doi:10.1016/j.baae.2005.07.001

Stone GN, Schönrogge K (2003) The adaptive significance of insect gall morphology. Trends Ecol Evol 18:512-522. doi:10.1016/S01695347(03)00247-7

Stone GN, Schonrogge K, Atkinson RJ, Bellido D, Pujade-Villar J (2002) The population biology of oak gallwasps (Hymenoptera: Cynipidae). Annu Rev Entomol 47:633-668. doi:10.1146/annurev. ento.47.091201.145247

Suzuki D, Fukushi Y, Ashimoto SI (2009) Do aphid galls provide good nutrients for the aphids? Comparisons of amino acid concentrations in galls among Tetraneura species (Aphididae: Eriosomatinae). Arthropod Plant Interact 3:241-247. doi:10.1007/s11829-0099064-9

Suzuki H, Yokokura J, Ito T, Arai R, Yokoyama C, Toshima H, Nagata S, Asami T, Suzuki Y (2014) Biosynthetic pathway of the phytohormone auxin in insects and screening of its inhibitors. Insect Biochem Mol Biol 53:66-72. doi:10.1016/j.ibmb.2014.07.008

Suzuki AYM, Bedetti CS, Isaias RMS (2015) Detection and distribution of cell growth regulators and cellulose microfibrils during the development of Lopesia sp. galls on Lonchocarpus cultratus (Fabaceae). Botany 93:435-444. doi:10.1139/cjb-2015-0012

Tooker JF, Helms AM (2014) Phytohormone dynamics associated with gall insects, and their potential role in the evolution of the gallinducing habit. J Chem Ecol 40:742-753. doi:10.1007/s10886014-0457-6

USDA-NRCS (2008) Plant guide: narrowleaf cottonwood Populus angustifolia James. http://plants.usda.gov/plantguide/pdf/cs_poan3. pdf. Accessed 14 April 2015

Vecchi C, Menezes NL, Oliveira DC, Ferreira BG, Isaias RMS (2013) The redifferentiation of nutritive cells in galls induced by Lepidoptera on Tibouchina pulchra (Cham.) Cogn. reveals predefined patterns of plant development. Protoplasma 250:13631368. doi:10.1007/s00709-013-0519-6

Whitham TG (1979) Territorial behaviour of Pemphigus gall aphids. Nature 279:324-325. doi:10.1038/279324a0

Whitham TG (1980) The theory of habitat selection: examined and extended using Pemphigus aphids. Am Nat 115:449-466. doi:10. $1086 / 283573$

Whitham TG (1992) Ecology of Pemphigus gall aphids. In: Shorthouse JD, Rohfritsch O (eds) Biology of insect induced galls. Oxford University Press, New York, pp 225-228

Whitham TG, Bailey JK, Schweitzer JA, Shuster SM, Bangert RK, LeRoy CJ, Lonsdorf EV, Allan GJ, DiFazio SP, Potts BM, Fischer DG, Gehring CA, Lindroth RL, Marks JC, Hart SC, Wimp GM, Wooley SC (2006) A framework for community and ecosystem 
genetics: from genes to ecosystems. Nat Rev Genet 7:510-523. doi: 10.1038/nrg 1877

Whitham TG, DiFazio SP, Schweitzer JA, Shuster SM, Allan GJ, Bailey JK, Woolbright SA (2008) Extending genomics to natural communities and ecosystems. Science 320:492-495. doi:10.1126/science. 1153918

Williams MAJ (1994) Plant galls: organisms, interactions, populations. Clarendon Press

Wool D (2004) Galling aphids: specialization, biological complexity, and variation. Annu Rev Entomol 49:175-192. doi:10.1146/annurev. ento.49.061802.123236

Wool D (2005) Gall-inducing aphids: biology, ecology, and evolution. In: Raman A, Schaefer CW, Withers TM (eds) Biology, ecology, and evolution of gall-inducing arthropods, volume 1. Science Publishers, Inc, Enfield, pp 73-132
Wool D, Bar-El N (1995) Population ecology of the galling aphid Forda formicaria Von Heyden in Israel: abundance, demography and gall structure. Isr J Zool 41:175-192

Wool D, Aloni R, Ben-Zvi O, Wollberg M (1998) A galling aphid furnishes its home with a built-in pipeline to the host food supply. In: Simpson SJ, Mordue AJ, Hardie J (eds) 10th International symposium on insect-plant relationships, pp 183-186

Wool D, Aloni R, Ben-Zvi O, Wollberg M (1999) A galling aphid furnishes its home with a built-in pipeline to the host food supply. Entomol Exp Appl 91:183-186. doi:10.1046/j.1570-7458.1999.00482.x

Yamaguchi H, Tanaka H, Hasegawa M, Tokuda M, Asami T, Suzuki Y (2012) Phytohormones and willow gall induction by a gall-inducing sawfly. New Phytol 196:586-595. doi:10.1111/j.1469-8137.2012.04264.x

Zhang G, Chen X (1999) Study on the phylogeny of Pemphigidae (Homoptera: Aphidinea). Acta Entomol Sin 42:176-184 